\title{
The Synergistic Financial Effect of Corporate Political Activities: The Case of Listed Canadian Companies
}

\author{
Saidatou Dicko ${ }^{1}$ \\ ${ }^{1}$ Full Professor, Accounting department, School of management, Université du Québec à Montréal (UQAM), \\ Canada \\ Correspondence: Prof. Saidatou Dicko, Accounting department, School of management, Université du Québec à \\ Montréal (UQAM), Canada.
}

Received: November 16, 2020

Accepted: December 21, 2020

Online Published: December 28, 2020

doi:10.5539/ibr.v14n1p102

URL: https://doi.org/10.5539/ibr.v14n1p102

\begin{abstract}
Corporate political activities can bring genuine political capital to firms and are an effective way to access key resources to boost financial capital and maximize profits. These activities fall into three categories: coopting ex-politicians to decision-making bodies (board of directors and top management) to benefit from their social capital; lobbying to directly influence public policy; and making financial contributions to the activities of political parties and committees. This study asks the following question: what is the combined effect of two of these activities (political connections and lobbying) on the financial and accounting indicators of Canadian listed companies? We argue that engaging in corporate political activities allows firms to accumulate a type of political capital that we define as the sum of all political activities conducted by an individual company. To perform our research, we analyzed Canadian companies listed on the S\&P/TSX composite index from 2012 through 2016. Results show that firms with this type of political capital are generally in a better financial position than those without it. A significant correlation was found between a firm's political capital and its main sources of financing (equity and long-term debt) as well as with its ROE. Political capital has more positive impacts on key firm financial indicators than does each type of political activity on its own (synergistic effect).
\end{abstract}

Keywords: political capital, political connections, lobbying, corporate political activities

\section{Introduction}

It is widely accepted that the political and business worlds are becoming increasingly intertwined and that politicians of every stripe are in favour of pro-business measures in the name of job creation. The interests of companies (especially large international corporations) are therefore served by maintaining close ties to the political class. As society's representatives, politicians have the fundamental role of regulating the sharing of collective resources; accordingly, companies derive an advantage by controlling political decisions, as this allows them easier access to these resources. The financial dependence of politicians on companies is increasingly enhancing the control that the latter exercise over them. Breton and Pesqueux (2006) argue that companies influence society because they affect its representatives (politicians), especially by the funding they provide and the control they then acquire over public regulations and policies. To exercise this political control, companies are resolutely engaged in numerous political activities that make it possible for them to accrue the real political capital necessary to their success and accomplishments. The literature has identified three main corporate political activities: nomination of ex-politicians to the board of directors or top management (political connections); lobbying; and funding political parties and committees.

In the literature, corporate political activities are analyzed from various theoretical perspectives. Whereas political science scholars are more interested in the reasons (why?) and the process (how?) of these activities, management and economics researchers have focused on their financial impact. Studies on corporate political activities adopt two main views of the role of companies in society, one based on social contract considerations and the other on competition and the market. The former holds that companies are essentially social institutions that have a contract with society as a whole. This contract allows them to use collective resources within the limits of the law to create and effectively disseminate wealth, which is presumably proportional to the recipient's participation in the production process or to the value of each factor of production in a market. From this standpoint, corporate political activities or influencing public policies is the best way for companies to avoid 
fulfilling their social contract, for example, by impeding tax regulation.

However, from a competition and market standpoint, companies face risks and must deal with them by conducting political activities. In fact, with expanding globalization and competition, each company faces major challenges that may affect growth and longevity. Companies must continually renew themselves, and to that end must rely on resources in their environment. However, those resources may diminish when new actors make inroads into the market. Companies must therefore apply innovative strategies to access these key resources and survive and prosper. One main strategy that can strengthen their competitive advantage is to conduct corporate political activities (Hadani 2007). These activities are considered an effective way to obtain the resources needed to increase financial capital and thus maximize profits.

The business world often views regulations and political decisions as a threat. The economic model perspective suggests that the market should regulate itself, without any intervention from the State. Companies must remain vigilant to these interventions, which come in the form of regulations of economic and market activities. Corporate political activities are therefore used as means to confront regulatory threats and preserve economic benefits.

Consequently, companies are stepping up their initiatives and applying greater political pressure to prevent wide-scale regulation of their activities. Indeed, power has now shifted from the world of states to the world of business, as described in the literature: "[There is] no question that business in general, and transnational corporations (TNCs) in particular, have become a political force that has to be taken into account" (Fuchs and Lederer 2007, p.1). More specifically, corporate management literature recognizes that firms leverage political pressure as a competitive strategy: "Corporate political action (CPA) is defined as any deliberate firm action intended to influence governmental policy or process" (Getz 1997, p. 32).

An increasing body of studies on firm political activities clearly demonstrates that the political influence of firms is growing and that firms are widely capitalizing on this benefit. In the U.S., a number of studies have investigated the impact of such activities on access to specific resources (public contracts and loans) and firm financial performance (Goldman et al., 2013; Chen et al., 2015). In Canada, several studies have shown that listed companies hold the lion's share (more than 50\%) of political connections and that such connections benefit firms in terms of performance and access to some resources, including public contracts (Dicko 2016).

However, most of the studies on corporate political activities hone in on only one of the three categories of corporate political activities. In the Canadian context in particular, no study has yet examined the combined effect of these activities. For this reason, we have decided to analyze the impact they wield jointly on the financial and accounting indicators of Canadian listed companies. More specifically, we aim to know whether simultaneous engagement in two political activities, specifically corporate political connections and lobbying, results in a synergistic effect. This study is the first of its kind in the Canadian setting. We base our reasoning on the hypothesis that combining certain political activities allows firms to accrue genuine political capital and obtain more benefits than engaging in only one activity at a time. In this study, we consider that a firm possesses political capital when it engages in the two corporate political activities we have selected to analyze. We draw not only on the management and economic perspective and resource dependence theory for our research, but we also refer to social capital theory as we look at firms' political connections built through the social networks of board and executive members.

The study draws on five-year data (2012 through 2016) on companies listed on the S\&P/TSX composite index, a body of companies with the highest capitalization. Results show that a combination of corporate political activities (as political capital) has a more positive impact on the firm's key financial indicators than each activity alone. This confirms our research assumption that conducting joint political activities is more beneficial than engaging in them one at a time. Our results also confirm resource dependence theory whereby political activities are a method for firms to deal with their environmental constraints and gain access to key resources they need to remain competitive and succeed. Lastly, we find that Canadian companies must keep increasing their political activity output.

\section{Theoretical Foundations}

As mentioned previously, the corporate management literature considers that corporate political activities are a strategic factor allowing firms to reinforce their competitive advantage (Hadani 2007). From that perspective, these activities could be considered a method by which the firm can obtain the key resources it needs to develop and succeed and therefore to improve its competitiveness. As described in the literature, these resources can also be obtained and often occur through the companies' social networks: "Businesses, like legislators, build and utilize network ties in helping to decide when and to what degree to engage in political activity" (Kowal, 2018, p. 
100). For these reasons, our research setting is based on two complementary theories: social capital and resource dependence theories.

\subsection{Resource Dependence Theory}

According to this theory, the survival and even the success of an organization depend on its ability to manage its relations with the environment. The organization relies on its environment to the extent that its operations are made possible with the help of the resources that come from the environment. Depending on its main activity and operating conditions, the organization has specific needs in relation to its environment and must therefore find ways to connect to the environment to gain access to the required resources. More specifically, "organizations require personnel, money, social legitimacy, customers, and a variety of technological and material inputs in order to continue to function" (Pfeffer 1981, p. 101).

Firms' political activities are considered an appropriate way to connect to the environment, especially the public policy environment. These activities allow firms to control their environment and ultimately obtain the key resources they need. These resources may be financial (for example, obtaining public procurement contracts or subsidies) or non-financial (such as blocking the adoption of laws detrimental to companies). For example, the appointment of an ex-politician to the board (political connections) could give the firm insight into political inner workings and be an advantage when bidding on public contracts or requesting government funding. Similarly, lobbying could help the firm not only to dodge over-regulation (considered a competitive drawback) but also to be at the forefront of any government opportunity.

One preferred corporate political activity is to nominate ex-politicians to the board of directors or the executive. These types of appointees are favoured because they have what is called "social capital", an essential factor in leveraging other types of capital, such as funding. In fact, according to Pierre Bourdieu (1986), social capital can be converted to economic capital. This means that a business could use the social capital of individuals within the organization to access the resources that it needs in the environment. Thus, the social capital of directors and executives could be leveraged to acquire resources for the good of the organization. In keeping with this idea, resource dependence theoreticians affirm that directors are a means for the organization to have favourable relationships with the environment, acquire the resources necessary for its success, communicate and receive information, and obtain legitimacy in the eyes of external organizations. When the organization faces difficulties resulting from lack of control over its environment, it can use its board of directors as a way to co-opt important external organizations on which it is dependent (Pfeffer, 1972; 1973; Pfeffer and Salancik, 1978). An organization can thus appoint directors from financial institutions, large organizations (economic and social) or political circles and thereby obtain financial, strategic, political, and social support from all these organizations.

\subsection{Social Capital Theory}

We learn from sociologist Pierre Bourdieu that individuals must each take a social trajectory that determines their social position in a socially defined space. This social position characterizes what Bourdieu calls "present capital" (1979, p. 109), in opposition to "initial capital," which, depending on collective events (social crises or other events), individual events (meetings, relationships, etc.) or institutionalized events (clubs, family gatherings, old friendships, etc.), transforms into present capital. Bourdieu (1979, p. 114) stressed that social capital has three dimensions: volume of capital, composition of capital and change in these two properties over time, the third dimension representing the social trajectory of individuals occupying a social space. It is the volume of capital, defined as the set of actually usable resources and powers-economic, cultural and social capital - which is the factor that distinguishes the main classes in society. Therefore, an individual's social position at a particular time in a socially defined space depends on his cultural capital (inherited and/or educational capital), economic capital and social capital. The sum of these three types of capital determine at moment $\mathrm{X}$ and in temporal space $\mathrm{Y}$ an individual's present capital.

According to Bourdieu, social capital is defined as "a capital of social connections, honourability and respectability that is often essential in winning and keeping the confidence of high society, and with it a clientele, and may be drawn on, for example, in making a political career (Bourdieu, 1979, p. 122).

For Bourdieu (1980), social capital represents the social effects resulting from a group's ability to mobilize its cultural and economic capital. A group may be defined and constituted as a family, alumni of elite schools, exclusive clubs, nobility, and so on. This means that capital attracts capital; in other words, the acquisition of social capital can occur only in a social space where other members of society also possess cultural capital, economic capital and social capital. Possessing cultural and economic capital allows for easier access to social capital, which provides useful types of support. 
Thus, access to capital becomes difficult for those without other forms of capital, such as those from underprivileged environments, even if they acquire economic capital by some good fortune (e.g. winning the lottery). This is all the more true when one considers, as Bourdieu did, that the different social classes are located on a spectrum ranging from those who are best provided with both economic and cultural capital (owners and managers) to those who are most deprived in both respects (office workers, labourers and agricultural workers) (Bourdieu, 1979, p. 114). In addition, cultural capital and economic capital may be converted into social capital.

Bourdieu also defines social capital as "the aggregate of the actual or potential resources which are linked to possession of a durable network of more or less institutionalized relationships of mutual acquaintance or recognition" (Bourdieu, 1979, p. 248-249). Social capital comes from belonging to a group constituted by a set of agents who not only have common properties but also are united by useful and durable relationships. According to Portes (1998, p. 3-4), Bourdieu's definitions highlight two major components of social capital: (1) social relations in themselves (networks), which enable individuals to access resources owned by their partners (in the network), and (2) the extent and quality of these resources. In this sense, we can define social capital as a set of resources and social relations. Ballet (2005, p. 78) points out that social capital is frequently conceived of as a set of social relationships for cooperation, cohesion and generating benefits.

Accordingly, corporate political activities, and especially political connections, are primarily based on the social capital of powerful individuals within the organization, i.e. directors, executives, and shareholders. These activities allow the firm to accrue genuine political capital, an extremely valuable asset for acquiring mainly financial resources, and therefore maximizing profits.

\section{Financial Impact of Corporate Political Activities}

Of the three types of corporate political activities, political connections have received the most attention, most likely due to the difficulty of obtaining accurate and reliable data. Most prior literature focused on the impact of firms' political connections on their financial performance and access to resources, such as loans and contracts. This research was carried out not only in the U.S. (Goldman et al., 2009), but also in Canada (Dicko and El Ibrami, 2013; Dicko and Khemakhem, 2015) as well as elsewhere in the world (Claessens et al., 2008 in Brazil; Ang et al., 2013 in Singapore; Boubakri et al., 2013 on a sample of 77 countries; Brockman et al., 2013 on 22 countries; Li and Xia, 2013 in China).

In the Canadian context, Dicko (2016) demonstrated that politically connected Canadian firms listed on the S\&P/TSX composite index are awarded more numerous and lucrative federal government contracts than non-politically connected firms are. Similar results were obtained by Goldman et al. (2013) and Wang (2014) in the U.S. Dicko and Khemakhem (2015) also show that the political connections of S\&P/TSX Canadian firms are positively and significantly related to their return on assets. In their study of the U.S. context, Goldman et al. (2009) demonstrate a positive abnormal stock return following the announcement of the nomination of a politically connected individual to the board of an S\&P 500 company. In Brazil, Claessens et al. (2008) show that Brazilian firms that contributed to (elected) federal deputies during the 1998 and 2002 election periods experienced higher stock returns than firms that did not. They also found that contributing firms substantially increased their bank financing relative to a control group after each election, indicating that access to bank finance is an important channel through which political connections operate.

Research on the financial impact of corporate lobbying activities is scant, except for studies in the U.S. Chen et al. (2015) demonstrated that U.S. corporate lobbying activities are positively associated with the firms' accounting and market performance, whereas Skaife et al. (2017) concluded that lobbying in the U.S. fails to enrich stockholders (measured by abnormal returns) even though the activities are associated with an increase in executive compensation. Unsal et al. (2016) confirm not only that lobbying activities in the U.S. do not improve firm performance, but that the scope of these activities depends on the political leanings of the CEO. Firms with Republican CEOs spend more on lobbying than those with a Democratic or politically neutral chief, but experience more negative effects on financial performance.

Our study stands apart by the fact that it analyzes the joint impact of two political activities on specific firm financial and accounting indicators. Although the direction of this impact cannot be predicted on the basis of the few prior Canadian studies on individual corporate political activities, the trend of these prior findings indicates that such activities will have a positive impact on the accounting and financial performance indicators of Canadian organizations. We thus hypothesize that:

\section{H1: Firms' political connections have a positive impact on their financial indicators.}

H2: Firms'lobbying has a positive impact on their financial indicators. 
H3: Combining political connections and lobbying enhances firm financial indicators more than carrying out these activities separately.

\section{Research Method}

\subsection{Study Sample and Data Sources}

To conduct this study and meet our research objectives, we examined Canadian firms on the S\&P/TSX composite index with data from the five most recent years, i.e. 2012 through 2016. Of the 300 firms selected, the index's 30 financial institutions and insurance companies were eliminated, as were those companies not consistently on the index or for which data were missing for the five-year period. At the end of the tally, 214 firms were analyzed.

The list of organizations and the set of financial data were downloaded from the Compustat database. Data on firm lobbying activities were hand collected from the website of the Commissioner of Lobbying of Canada at https://lobbycanada.gc.ca/eic/site/012.nsf/fra/h_00950.html. Data on political connections were hand collected from the BoardEx database, which lists detailed profiles of directors and executives of the largest listed companies across the world.

\subsection{Statistical Analyses Performed and Study Variables}

To fulfill the research objective, we performed two types of statistical analysis: bidirectional analyses to understand correlation links between political activities and the selected financial indicators; and multidirectional analyses to see the impact when several other factors are taken into account simultaneously.

Three types of variables are used in this study: political activities, the selected financial indicators, and control variables for multidirectional analyses.

\subsubsection{Political Activities Variables}

We chose to analyze the combined impact of two political activities, political connections (i.e. appointment of ex-politicians to the firm's decision-making bodies) and lobbying activities. Here is how these variables were measured:

- Political connections: the literature generally considers a firm to be politically connected when at least one member of the board of directors or top management or the principal shareholder has been a member of parliament (federal, provincial or regional), a prime minister, a minister, a cabinet member, or a political advisor (Faccio, 2006). We apply this definition in this study and use the dichotomous variable "Political Connections", which equals 1 if the firm is connected, 0 otherwise.

- Lobbying activities: the dichotomous variable "Lobbying" is used, equalling 1 if the firm conducted a lobbying activity during the study year, and 0 otherwise.

\subsubsection{Financial Indicator Variables}

We examine only accounting and financial variables to discover their correlations with the two corporate political activities, political connections, and lobbying activities. We chose two types of financial indicators: accounting and market performance and financing sources. For accounting and market performance, the following indicators are examined:

- ROA: earnings before interest and taxes divided by total assets;

- ROE: earnings before interest and taxes divided by total equity;

- Earnings per share (EPS): earnings before interest and taxes divided by total outstanding common shares;

- Revenue: natural logarithm of total revenues;

- Market value: natural logarithm of market value for the study period.

For indicators relating to financing sources, we chose two to represent the two main sources recognized in accounting, equity and debt. The following two indicators measure both sources:

- Equity: natural logarithm of total equity;

- Long-term debt: natural logarithm of total long-term debt.

\subsubsection{Additional Control Variables for Multivariate Analyses}

As mentioned previously, regressions were performed to understand the impact of political activities on the financial performance of the firms under study. To that end, the following model was used: 
Financial Performance $=a 0+$ blPolitical connections +

b2Lobbying + b3Political connections $*$ Lobbying + b4Firm size +

$b 5$ Debt + b6Relative net cash flow + b7Relative PPE + b8Industry $+\varepsilon$

Where:

- Financial performance is measured by three indicators: ROA, ROE and EPS.

- Political connections: see above paragraphs.

- Lobbying: see above paragraphs.

- Political connections * Lobbying: this is an interaction variable that equals 1 if the firm is both politically connected and has lobbied. This variable measures the combined effect of the two political activities.

- Firm size: measured by the natural logarithm of total revenues.

- Debt ratio: this is the level of indebtedness measured by the ratio of long-term debt to total assets.

- Relative net cash flow: measured by total cash divided by total assets.

- Relative PPE: measured by net PPE assets divided by total assets.

- Industry: this is a dummy variable coded 1 to 19 , according to industry, as follows: 1 - agriculture, forestry, fishing and hunting; 2 - mining, quarries, and oil and gas extraction; 3 - utilities; 4 - building; 5 - manufacturing; 6 - wholesale trade; 7 - retail trade; 8 - transportation and storage; 9 - information and culture; 10 - finance and insurance; 11 - real estate and leasing; 12 - professional, scientific and technical services; 13 - business management; 14 - administrative services and support and waste management and remediation; 15 - educational services; 16 - health and social assistance; 17 - arts, entertainment and leisure; 18 - accommodation and food services; and 19 - other service industries.

\section{Results of Statistical Analyses and Discussion}

\subsection{Descriptive Statistics}

Table 1 shows that three industries make up $65 \%$ of the group, in the following proportions: mining, quarries and oil and gas extraction (35\%), manufacturing (18\%), and real estate $(12 \%)$. Other industries are represented in varying proportions, all of which are under $10 \%$ per industry. We can then expect that the three main industries will be overrepresented in lobbying activities and among politically connected firms.

Table 1. Industry

\begin{tabular}{|c|c|c|c|c|}
\hline & Frequency & Percent & $\begin{array}{c}\text { Valid } \\
\text { Percent }\end{array}$ & $\begin{array}{l}\text { Cumulative } \\
\text { Percent }\end{array}$ \\
\hline Mining, quarries, and oil and gas extraction & 375.00 & 35.00 & 35.00 & 35.00 \\
\hline Utilities & 70.00 & 6.50 & 6.50 & 41.60 \\
\hline Building & 20.00 & 1.90 & 1.90 & 43.50 \\
\hline Manufacturing & 191.00 & 17.90 & 17.90 & 61.30 \\
\hline Wholesale trade & 19.00 & 1.80 & 1.80 & 63.10 \\
\hline Retail trade & 55.00 & 5.10 & 5.10 & 68.20 \\
\hline Transportation and storage & 60.00 & 5.60 & 5.60 & 73.80 \\
\hline Information and culture & 80.00 & 7.50 & 7.50 & 81.30 \\
\hline Real estate and leasing & 130.00 & 12.10 & 12.10 & 93.50 \\
\hline Professional, scientific and technical services & 30.00 & 2.80 & 2.80 & 96.30 \\
\hline $\begin{array}{l}\text { Administrative services and support and waste management and } \\
\text { remediation }\end{array}$ & 10.00 & 0.90 & 0.90 & 97.20 \\
\hline Health and social assistance & 5.00 & 0.50 & 0.50 & 97.70 \\
\hline Arts, entertainment and leisure & 15.00 & 1.40 & 1.40 & 99.10 \\
\hline Accommodation and food services & 5.00 & 0.50 & 0.50 & 99.50 \\
\hline Other & 5.00 & 0.50 & 0.50 & 100.00 \\
\hline Total & 1070.00 & 100.00 & 100.00 & \\
\hline
\end{tabular}

Table 2 shows that $41 \%$ of the sample firms are politically connected, but only $27 \%$ of the sample has conducted any lobbying. The co-opting of ex-politicians to corporate decision-making bodies therefore appears to be a more popular political activity than attempts to exert direct influence through lobbying activities registered with the Commissioner of Lobbying. Table 3 shows that only $20 \%$ of the sample firms conducted both types of political activities by combining political connections and lobbying activities. 
Table 2. Frequencies of Political Connections and Lobbying

\begin{tabular}{lcc}
\hline & Frequency & Percent \\
\hline Political connections & & 59.3 \\
Non-connected firm & 635 & 40.7 \\
Politically connected firm & 435 & 100.0 \\
Total & 1070 & \\
& & \\
Lobbying & & 73.0 \\
Firm did not lobby & 781 & 27.0 \\
Firm lobbied & 289 & 100.0 \\
Total & 1070 & \\
\hline
\end{tabular}

Table 3. Political Connections and Lobbying Cross Tabulation

\begin{tabular}{|c|c|c|c|c|c|}
\hline & & & Lol & & \\
\hline & & & $\begin{array}{c}\text { Firm has not } \\
\text { lobbied }\end{array}$ & $\begin{array}{l}\text { Firm has } \\
\text { lobbied }\end{array}$ & Total \\
\hline Political connections & Non-connected firm & Count & 559 & 76 & 635 \\
\hline & & $\begin{array}{l}\% \quad \text { within } \\
\text { connections }\end{array}$ & $88.0 \%$ & $12.0 \%$ & $100.0 \%$ \\
\hline & & $\%$ within Lobbying & $71.6 \%$ & $26.3 \%$ & $59.3 \%$ \\
\hline & & $\%$ within total & $52.2 \%$ & $7.1 \%$ & $59.3 \%$ \\
\hline & Politically connected firm & Count & 222 & 213 & 435 \\
\hline & & $\begin{array}{l}\% \quad \text { within } \\
\text { connections }\end{array}$ & $51.0 \%$ & $49.0 \%$ & $100.0 \%$ \\
\hline & & $\%$ within Lobbying & $28.4 \%$ & $73.7 \%$ & $40.7 \%$ \\
\hline & & $\%$ within total & $20.7 \%$ & $19.9 \%$ & $40.7 \%$ \\
\hline
\end{tabular}

According to Table 4, four industries exhibit the highest proportions of political connections: mining at $24.4 \%$, followed by manufacturing at $19.5 \%$, information and culture at $11.5 \%$, and utilities at $10.3 \%$.

The same four industries lead in terms of lobbying activities (Table 5): mining at $28.7 \%$, manufacturing at $23.9 \%$, information and culture at $13.8 \%$, and utilities at $10.4 \%$.

Table 4. Industry and Political Connections Cross Tabulation

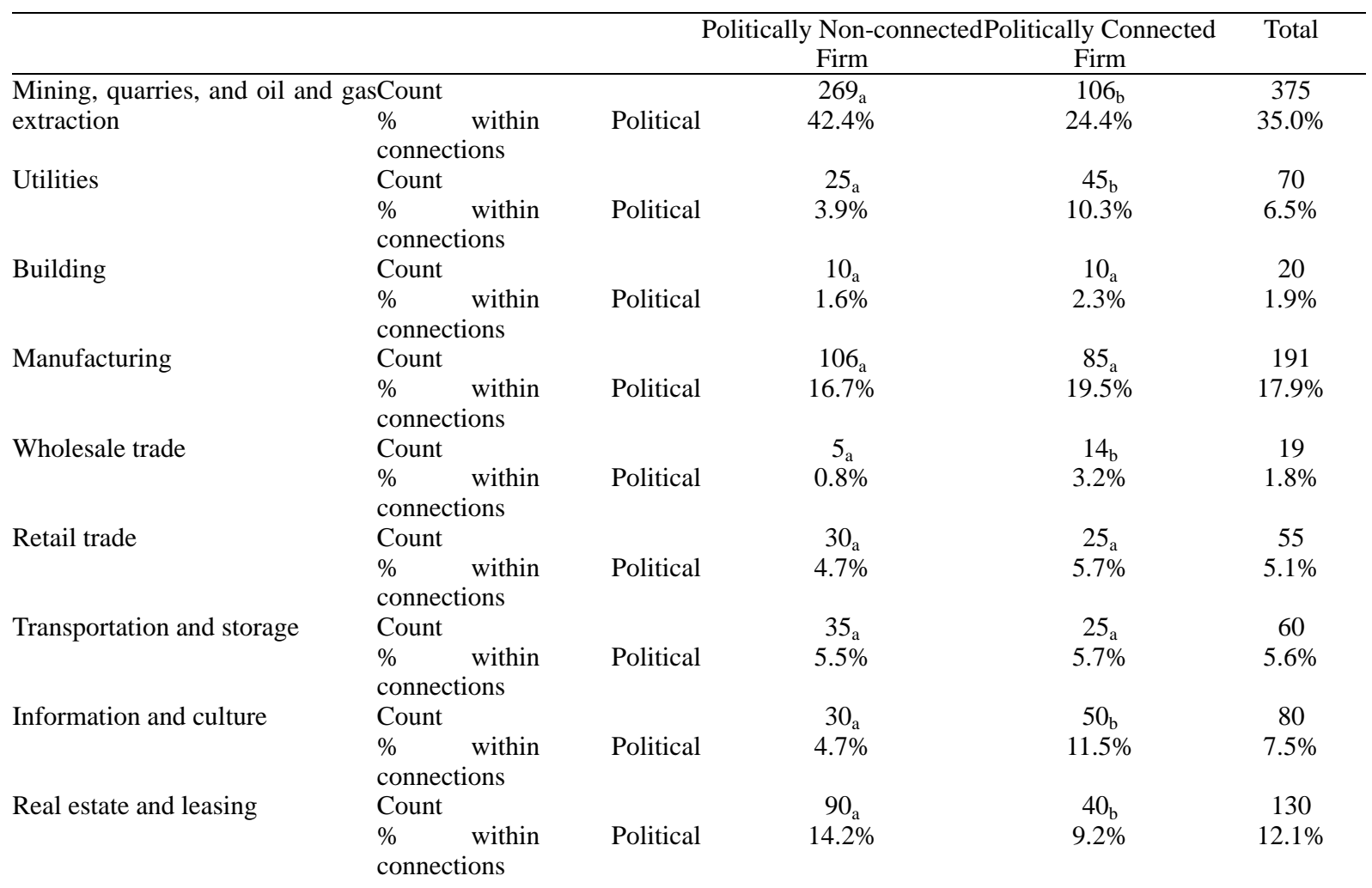




\begin{tabular}{|c|c|c|c|c|c|}
\hline $\begin{array}{l}\text { Professional, scientific a } \\
\text { technical services }\end{array}$ & $\begin{array}{l}\text { ndCount } \\
\% \text { within } \\
\text { connections }\end{array}$ & Political & $\begin{array}{l}10 \mathrm{a} \\
1.6 \%\end{array}$ & $\begin{array}{l}20_{\mathrm{b}} \\
4.6 \%\end{array}$ & $\begin{array}{c}30 \\
2.8 \%\end{array}$ \\
\hline $\begin{array}{l}\text { Administrative services a } \\
\text { support and waste manageme } \\
\text { and remediation }\end{array}$ & $\begin{array}{l}\text { ndCount } \\
\text { ent } \% \text { within } \\
\text { connections }\end{array}$ & Political & $\begin{array}{c}5 \mathrm{a} \\
0.8 \%\end{array}$ & $\begin{array}{c}5 \mathrm{a} \\
1.1 \%\end{array}$ & $\begin{array}{c}10 \\
0.9 \%\end{array}$ \\
\hline Health and social assistance & $\begin{array}{l}\text { Count } \\
\% \text { within } \\
\text { connections }\end{array}$ & Political & $\begin{array}{c}0_{\mathrm{a}} \\
0.0 \%\end{array}$ & $\begin{array}{c}5 \mathrm{~b} \\
1.1 \%\end{array}$ & $\begin{array}{c}5 \\
0.5 \%\end{array}$ \\
\hline Arts, entertainment and leisure & $\begin{array}{l}\text { Count } \\
\% \text { within } \\
\text { connections }\end{array}$ & Political & $\begin{array}{l}10 \mathrm{a} \\
1.6 \%\end{array}$ & $\begin{array}{c}5 \mathrm{a} \\
1.1 \%\end{array}$ & $\begin{array}{c}15 \\
1.4 \%\end{array}$ \\
\hline $\begin{array}{l}\text { Accommodation and } \\
\text { services }\end{array}$ & $\begin{array}{l}\text { odCount } \\
\% \text { within } \\
\text { connections }\end{array}$ & Political & $\begin{array}{c}5 \mathrm{a} \\
0.8 \%\end{array}$ & $\begin{array}{c}0_{\mathrm{a}} \\
0.0 \%\end{array}$ & $\begin{array}{c}5 \\
0.5 \%\end{array}$ \\
\hline Others & $\begin{array}{l}\text { Count } \\
\% \text { within } \\
\text { connections }\end{array}$ & Political & $\begin{array}{c}5 \mathrm{a} \\
0.8 \%\end{array}$ & $\begin{array}{c}0 \mathrm{a} \\
0.0 \%\end{array}$ & $\begin{array}{c}5 \\
0.5 \%\end{array}$ \\
\hline
\end{tabular}

Table 5. Industry and Lobbying Cross Tabulation

\begin{tabular}{|c|c|c|c|c|}
\hline \multirow{2}{*}{\multicolumn{2}{|c|}{ Mining, quarries, and oil and gasCount }} & Firm Lobbied & Firm Did Not Lobby & Total \\
\hline & & $292_{\mathrm{a}}$ & $83_{\mathrm{b}}$ & 375 \\
\hline \multirow{3}{*}{$\begin{array}{l}\text { extraction } \\
\text { Utilities }\end{array}$} & $\%$ within Lobbying & $37.4 \%$ & $28.7 \%$ & $35.0 \%$ \\
\hline & Count & $40_{\mathrm{a}}$ & $30_{\mathrm{b}}$ & 70 \\
\hline & $\%$ within Lobbying & $5.1 \%$ & $10.4 \%$ & $6.5 \%$ \\
\hline \multirow[t]{2}{*}{ Building } & Count & $14 \mathrm{a}$ & $6_{a}$ & 20 \\
\hline & $\%$ within Lobbying & $1.8 \%$ & $2.1 \%$ & $1.9 \%$ \\
\hline \multirow[t]{2}{*}{ Manufacturing } & Count & $122_{\mathrm{a}}$ & $69 \mathrm{~b}$ & 191 \\
\hline & $\%$ within Lobbying & $15.6 \%$ & $23.9 \%$ & $17.9 \%$ \\
\hline \multirow[t]{2}{*}{ Wholesale trade } & Count & $19 \mathrm{a}$ & $\mathrm{O}_{\mathrm{b}}$ & 19 \\
\hline & $\%$ within Lobbying & $2.4 \%$ & $0.0 \%$ & $1.8 \%$ \\
\hline \multirow[t]{2}{*}{ Retail trade } & Count & $44_{a}$ & $11_{\mathrm{a}}$ & 55 \\
\hline & $\%$ within Lobbying & $5.6 \%$ & $3.8 \%$ & $5.1 \%$ \\
\hline \multirow[t]{2}{*}{ Transportation and storage } & Count & $34_{a}$ & $26_{b}$ & 60 \\
\hline & $\%$ within Lobbying & $4.4 \%$ & $9.0 \%$ & $5.6 \%$ \\
\hline \multirow[t]{2}{*}{ Information and culture } & Count & $40_{\mathrm{a}}$ & $40_{\mathrm{b}}$ & 80 \\
\hline & $\%$ within Lobbying & $5.1 \%$ & $13.8 \%$ & $7.5 \%$ \\
\hline \multirow[t]{2}{*}{ Real estate and leasing } & Count & $128_{\mathrm{a}}$ & $2 \mathrm{~b}$ & 130 \\
\hline & $\%$ within Lobbying & $16.4 \%$ & $0.7 \%$ & $12.1 \%$ \\
\hline \multicolumn{2}{|c|}{ Professional, scientific and technicalCount } & $13_{\mathrm{a}}$ & $17_{\mathrm{b}}$ & 30 \\
\hline services & $\%$ within Lobbying & $1.7 \%$ & $5.9 \%$ & $2.8 \%$ \\
\hline \multicolumn{2}{|c|}{ Administrative services and supportCount } & $10_{\mathrm{a}}$ & $0_{\mathrm{a}}$ & 10 \\
\hline \multicolumn{2}{|c|}{$\begin{array}{l}\text { and waste management and \% within Lobbying } \\
\text { remediation }\end{array}$} & $1.3 \%$ & $0.0 \%$ & $0.9 \%$ \\
\hline \multirow[t]{2}{*}{ Health and social assistance } & Count & $5 \mathrm{a}$ & $0_{\mathrm{a}}$ & 5 \\
\hline & $\%$ within Lobbying & $0.6 \%$ & $0.0 \%$ & $0.5 \%$ \\
\hline \multirow[t]{2}{*}{ Arts, entertainment and leisure } & Count & $12 \mathrm{a}$ & $3_{\mathrm{a}}$ & 15 \\
\hline & $\%$ within Lobbying & $1.5 \%$ & $1.0 \%$ & $1.4 \%$ \\
\hline \multirow[t]{2}{*}{ Accommodation and food services } & Count & $3_{\mathrm{a}}$ & $2 \mathrm{a}$ & 5 \\
\hline & $\%$ within Lobbying & $0.4 \%$ & $0.7 \%$ & $0.5 \%$ \\
\hline \multirow[t]{2}{*}{ Others } & Count & $5 \mathrm{a}$ & $0_{\mathrm{a}}$ & 5 \\
\hline & $\%$ within Lobbying & $0.6 \%$ & $0.0 \%$ & $0.5 \%$ \\
\hline
\end{tabular}

Again, these industries lead in terms of combined political activities (Table 6): manufacturing (22.5\%), mining (22.1\%), information and culture (18.8\%) and utilities (12.2\%). The first two industries stand out from the rest of sample as they face increasing challenges, particularly regarding global environmental issues. Although free from any immediate threats from Canadian regulations, particularly because Canada is an oil country, these industries are nonetheless challenged by the current Liberal government's creation of a carbon market. This could explain why these industries are more politically active than the others. Around the world, companies with high environmental impacts are facing unprecedented regulatory constraints, even in the U.S. For example, Brulle (2018) shows that from 2000-2016, U.S. companies spent over $\$ 2$ billion on lobbying about climate change regulation, this amount representing $3.9 \%$ of total lobbying expenditures. 
Table 6. Industry, Political Connections and Lobbying Cross Tabulation

\begin{tabular}{|c|c|c|c|c|}
\hline & & $\begin{array}{c}\text { Firm Carried Out None } \\
\text { of These Activities }\end{array}$ & $\begin{array}{l}\text { Firm Lobbied and Is } \\
\text { Politically Connected }\end{array}$ & Total \\
\hline $\begin{array}{l}\text { Mining, quarries, and oil and } \\
\text { extraction }\end{array}$ & $\begin{array}{l}\text { gasCount } \\
\% \quad \text { within Political } \\
\% \text { connections and Lobbying }\end{array}$ & $\begin{array}{c}328_{\mathrm{a}} \\
38.3 \%\end{array}$ & $\begin{array}{c}47_{\mathrm{b}} \\
22.1 \%\end{array}$ & $\begin{array}{c}375 \\
35.0 \%\end{array}$ \\
\hline Utilities & $\begin{array}{l}\text { Count } \\
\% \text { within Political } \\
\text { connections and Lobbying }\end{array}$ & $\begin{array}{c}44_{a} \\
5.1 \%\end{array}$ & $\begin{array}{c}26_{\mathrm{b}} \\
12.2 \%\end{array}$ & $\begin{array}{c}70 \\
6.5 \%\end{array}$ \\
\hline Building & $\begin{array}{l}\text { Count } \\
\% \quad \text { within Political } \\
\text { connections and Lobbying }\end{array}$ & $\begin{array}{c}14 \mathrm{a} \\
1.6 \%\end{array}$ & $\begin{array}{c}6_{\mathrm{a}} \\
2.8 \%\end{array}$ & $\begin{array}{c}20 \\
1.9 \%\end{array}$ \\
\hline Manufacturing & $\begin{array}{l}\text { Count } \\
\% \quad \text { within Political } \\
\text { connections and Lobbying }\end{array}$ & $\begin{array}{c}143_{\mathrm{a}} \\
16.7 \%\end{array}$ & $\begin{array}{c}48 \mathrm{~b} \\
22.5 \%\end{array}$ & $\begin{array}{c}191 \\
17.9 \%\end{array}$ \\
\hline Wholesale trade & $\begin{array}{l}\text { Count } \\
\% \quad \text { within Political } \\
\text { connections and Lobbying }\end{array}$ & $\begin{array}{c}19 \mathrm{a} \\
2.2 \%\end{array}$ & $\begin{array}{c}0_{\mathrm{b}} \\
0.0 \%\end{array}$ & $\begin{array}{c}19 \\
1.8 \%\end{array}$ \\
\hline Retail trade & $\begin{array}{l}\text { Count } \\
\% \quad \text { within Political } \\
\text { connections and Lobbying }\end{array}$ & $\begin{array}{c}44 \mathrm{a} \\
5.1 \%\end{array}$ & $\begin{array}{c}11_{\mathrm{a}} \\
5.2 \%\end{array}$ & $\begin{array}{c}55 \\
5.1 \%\end{array}$ \\
\hline Transportation and storage & $\begin{array}{l}\text { Count } \\
\% \quad \text { within Political } \\
\text { connections and Lobbying }\end{array}$ & $\begin{array}{c}40 \mathrm{a} \\
4.7 \%\end{array}$ & $\begin{array}{c}20_{\mathrm{b}} \\
9.4 \%\end{array}$ & $\begin{array}{c}60 \\
5.6 \%\end{array}$ \\
\hline Information and culture & $\begin{array}{l}\text { Count } \\
\% \quad \text { within Political } \\
\text { connections and Lobbying }\end{array}$ & $\begin{array}{c}40 \mathrm{a} \\
4.7 \%\end{array}$ & $\begin{array}{c}40_{\mathrm{b}} \\
18.8 \%\end{array}$ & $\begin{array}{c}80 \\
7.5 \%\end{array}$ \\
\hline Real estate and leasing & $\begin{array}{l}\text { Count } \\
\% \text { within Political } \\
\text { connections and Lobbying }\end{array}$ & $\begin{array}{c}129 \mathrm{a} \\
15.1 \%\end{array}$ & $\begin{array}{c}1_{\mathrm{b}} \\
0.5 \%\end{array}$ & $\begin{array}{c}130 \\
12.1 \%\end{array}$ \\
\hline $\begin{array}{l}\text { Professional, scientific and techn } \\
\text { services }\end{array}$ & $\begin{array}{l}\text { icalCount } \\
\% \quad \text { within Political } \\
\text { connections and Lobbying }\end{array}$ & $\begin{array}{c}16 \mathrm{a} \\
1.9 \%\end{array}$ & $\begin{array}{l}14_{b} \\
6.6 \%\end{array}$ & $\begin{array}{c}30 \\
2.8 \%\end{array}$ \\
\hline $\begin{array}{l}\text { Administrative services and support } \\
\text { waste management and remediation }\end{array}$ & $\begin{array}{l}\text { andCount } \\
\% \text { within Political } \\
\text { connections and Lobbying }\end{array}$ & $\begin{array}{c}10 \mathrm{a} \\
1.2 \%\end{array}$ & $\begin{array}{c}0 \mathrm{a} \\
0.0 \%\end{array}$ & $\begin{array}{c}10 \\
0.9 \%\end{array}$ \\
\hline Health and social assistance & $\begin{array}{l}\text { Count } \\
\% \text { within Political } \\
\text { connections and Lobbying }\end{array}$ & $\begin{array}{c}5 \mathrm{a} \\
0.6 \%\end{array}$ & $\begin{array}{c}0 \mathrm{a} \\
0.0 \%\end{array}$ & $\begin{array}{c}5 \\
0.5 \%\end{array}$ \\
\hline Arts, entertainment and leisure & $\begin{array}{l}\text { Count } \\
\% \quad \text { within Political } \\
\text { connections and Lobbying }\end{array}$ & $\begin{array}{c}15 \mathrm{a} \\
1.8 \%\end{array}$ & $\begin{array}{c}0_{\mathrm{a}} \\
0.0 \%\end{array}$ & $\begin{array}{l}15 \\
1.4 \%\end{array}$ \\
\hline Accommodation and food services & $\begin{array}{l}\text { Count } \\
\% \quad \text { within Political } \\
\text { connections and Lobbying }\end{array}$ & $\begin{array}{c}5 \mathrm{a} \\
0.6 \%\end{array}$ & $\begin{array}{c}0 \mathrm{a} \\
0.0 \%\end{array}$ & $\begin{array}{l}5 \\
0.5 \%\end{array}$ \\
\hline Others & $\begin{array}{l}\text { Count } \\
\% \quad \text { within Political } \\
\text { connections and Lobbying }\end{array}$ & $\begin{array}{c}5 \mathrm{a} \\
0.6 \%\end{array}$ & $\begin{array}{c}0_{\mathrm{a}} \\
0.0 \%\end{array}$ & $\begin{array}{l}5 \\
0.5 \%\end{array}$ \\
\hline
\end{tabular}

\subsection{Results of Analyses of Variance (ANOVA)}

These tests highlight the traits that distinguish firms with political activities from the others. Politically connected firms are statistically significantly different from non-politically connected firms in terms of equity, long-term debt, market value, revenues, ROA, cash flow, and industry (see Table 7). Table 8 shows that politically connected firms have higher equity, long-term debt, market value, revenues, ROA, ROE, and EPS. These observations trend in the direction of previous studies that demonstrated that politically connected firms are wealthier and exhibit better financial indicators (Dicko, 2016; 2020). This first statistical result seems to confirm our first hypothesis. 
Table 7. ANOVA Results

Factor: Political Connections

\begin{tabular}{|c|c|c|c|c|c|c|}
\hline & & Sum of Squares & ddl & Mean Square & $\mathrm{F}$ & Sig. \\
\hline \multirow[t]{3}{*}{ (Ln) Total equity } & Between Groups & 191.726 & 1 & 191.726 & 118.070 & .000 \\
\hline & Within Groups & 1700.149 & 1047 & 1.624 & & \\
\hline & Total & 1891.875 & 1048 & & & \\
\hline \multirow[t]{3}{*}{ (Ln) Long-term debt } & Between Groups & 226.460 & 1 & 226.460 & 76.160 & .000 \\
\hline & Within Groups & 2765.324 & 930 & 2.973 & & \\
\hline & Total & 2991.784 & 931 & & & \\
\hline \multirow[t]{3}{*}{ (Ln) Market value } & Between Groups & 167.774 & 1 & 167.774 & 129.355 & .000 \\
\hline & Within Groups & 1226.966 & 946 & 1.297 & & \\
\hline & Total & 1394.739 & 947 & & & \\
\hline \multirow[t]{3}{*}{ (Ln) Revenues } & Between Groups & 429.671 & 1 & 429.671 & 197.152 & .000 \\
\hline & Within Groups & 2214.262 & 1016 & 2.179 & & \\
\hline & Total & 2643.933 & 1017 & & & \\
\hline \multirow[t]{3}{*}{ ROA } & Between Groups & .044 & 1 & .044 & 3.817 & .051 \\
\hline & Within Groups & 12.270 & 1061 & .012 & & \\
\hline & Total & 12.314 & 1062 & & & \\
\hline \multirow[t]{3}{*}{ ROE } & Between Groups & 4.413 & 1 & 4.413 & 2.449 & .118 \\
\hline & Within Groups & 1910.036 & 1060 & 1.802 & & \\
\hline & Total & 1914.449 & 1061 & & & \\
\hline \multirow[t]{3}{*}{ EPS } & Between Groups & 3034858.056 & 1 & 3034858.056 & .562 & .453 \\
\hline & Within Groups & 5687361980.898 & 1054 & 5395979.109 & & \\
\hline & Total & 5690396838.953 & 1055 & & & \\
\hline \multirow[t]{3}{*}{ Relative net cash flow } & Between Groups & .358 & 1 & .358 & 27.386 & .000 \\
\hline & Within Groups & 13.862 & 1061 & .013 & & \\
\hline & Total & 14.220 & 1062 & & & \\
\hline \multirow[t]{3}{*}{ Relative PPE } & Between Groups & .089 & 1 & .089 & .853 & .356 \\
\hline & Within Groups & 110.372 & 1061 & .104 & & \\
\hline & Total & 110.461 & 1062 & & & \\
\hline \multirow[t]{3}{*}{ Debt ratio } & Between Groups & 92.932 & 1 & 92.932 & 1.308 & .253 \\
\hline & Within Groups & 75298.691 & 1060 & 71.037 & & \\
\hline & Total & 75391.623 & 1061 & & & \\
\hline \multirow[t]{3}{*}{ Industry } & Between Groups & 73.990 & 1 & 73.990 & 4.754 & .029 \\
\hline & Within Groups & 16620.818 & 1068 & 15.563 & & \\
\hline & Total & 16694.807 & 1069 & & & \\
\hline
\end{tabular}

Table 8. Descriptive statistics

Factor: Political Connections

\begin{tabular}{|c|c|c|c|c|c|c|}
\hline & & $\mathrm{N}$ & Mean & St. deviation & Minimum & Maximum \\
\hline \multirow[t]{3}{*}{ (Ln) Equity } & & & & & & 10.438 \\
\hline & Firm is politically connected & 427 & 7.838 & 1.333 & 3.634 & 13.582 \\
\hline & Total & 1049 & 7.322 & 1.343 & 1.761 & 13.582 \\
\hline \multirow[t]{3}{*}{ (Ln) long-term debt } & Firm is not politically connected & 514 & 6.281 & 1.741 & -4.135 & 10.380 \\
\hline & Firm is politically connected & 418 & 7.272 & 1.702 & 1.253 & 11.288 \\
\hline & Total & 932 & 6.725 & 1.792 & -4.135 & 11.288 \\
\hline \multirow[t]{3}{*}{ (Ln) Market value } & Firm is not politically connected & 540 & 7.532 & 1.038 & 2.233 & 10.775 \\
\hline & Firm is politically connected & 408 & 8.381 & 1.259 & 5.945 & 11.201 \\
\hline & Total & 948 & 7.897 & 1.213 & 2.233 & 11.201 \\
\hline \multirow[t]{3}{*}{ (Ln) Revenue } & Firm is not politically connected & 585 & 6.624 & 1.517 & -1.007 & 10.665 \\
\hline & Firm is politically connected & 433 & 7.938 & 1.418 & 4.024 & 10.778 \\
\hline & Total & 1018 & 7.183 & 1.612 & -1.007 & 10.778 \\
\hline \multirow[t]{3}{*}{$\mathrm{ROA}$} & Firm is not politically connected & 630 & .042 & .130 & -1.609 & .560 \\
\hline & Firm is politically connected & 433 & .056 & .061 & -.306 & .270 \\
\hline & Total & 1063 & .048 & .107 & -1.609 & .560 \\
\hline \multirow[t]{3}{*}{ ROE } & Firm is not politically connected & 629 & .093 & .241 & -2.036 & 1.176 \\
\hline & Firm is politically connected & 433 & .224 & 2.082 & -20.156 & 35.3250 \\
\hline & Total & 1062 & .146 & 1.343 & -20.156 & 35.3250 \\
\hline \multirow[t]{3}{*}{ EPS } & Firm is not politically connected & 625 & 61.575 & 866.815 & -7.339 & 9223.372 \\
\hline & Firm is politically connected & 431 & 170.649 & 3483.685 & -5.664 & 9223.372 \\
\hline & Total & 1056 & 106.093 & 2322.442 & -7.339 & 9223.372 \\
\hline \multirow[t]{3}{*}{ Relative net cash flow } & Firm is not politically connected & 630 & .088 & .138 & .000 & .804 \\
\hline & Firm is politically connected & 433 & .051 & .063 & .000 & .383 \\
\hline & Total & 1063 & .073 & .115 & .000 & .804 \\
\hline
\end{tabular}




\begin{tabular}{llccccc}
\hline Relative PPE & Firm is not politically connected & 630 & .455 & .334 & .000 & .987 \\
& Firm is politically connected & 433 & .474 & .303 & .000 & .979 \\
Debt ratio & Total & 1063 & .463 & .322 & .000 & .987 \\
& Firm is not politically connected & 629 & .518 & .916 & -10.148 & 9.168 \\
& Firm is politically connected & 433 & 1.120 & 13.156 & -180.990 & 146.750 \\
Industry & Total & 1062 & .764 & 8.429 & -180.990 & 146.750 \\
& Firm is not politically connected & 635 & 5.52 & 4.104 & 2 & 19 \\
& Firm is politically connected & 435 & 6.06 & 3.701 & 2 & 17 \\
& Total & 1070 & 5.74 & 3.952 & 2 & 19 \\
\hline
\end{tabular}

The same observation applies to lobbying: lobbying firms differ from other firms in statistically significant ways in terms of equity, long-term debt, market value, revenues, ROE, cash flow, debt, and PPE (see Table 9). As with politically connected firms, lobbying firms exhibit higher equity, long-term debt, market value, revenues, ROE, and EPS (Table 10). These results go in the same direction as our second hypothesis.

Lastly, when both components of political capital (political connections and lobbying) are considered together, we note statistically significant differences between firms with and without political capital in terms of the same indicators noted for lobbying, i.e. equity, long-term debt, market value, revenues, ROE, cash flow, debt, and PPE (see Table 11).

Table 9. ANOVA Results

Factor: Lobbying

\begin{tabular}{|c|c|c|c|c|c|c|}
\hline & & Sum of Squares & ddl & Mean Square & $\mathrm{F}$ & Sig. \\
\hline \multirow[t]{3}{*}{ (Ln) Total equity } & Between Groups & 390.995 & 1 & 390.995 & 272.755 & .000 \\
\hline & Within Groups & 1500.879 & 1047 & 1.434 & & \\
\hline & Total & 1891.875 & 1048 & & & \\
\hline \multirow[t]{3}{*}{ (Ln) Long-term debt } & Between Groups & 456.349 & 1 & 456.349 & 167.389 & .000 \\
\hline & Within Groups & 2535.435 & 930 & 2.726 & & \\
\hline & Total & 2991.784 & 931 & & & \\
\hline \multirow[t]{3}{*}{ (Ln) Market value } & Between Groups & 335.115 & 1 & 335.115 & 299.180 & .000 \\
\hline & Within Groups & 1059.625 & 946 & 1.120 & & \\
\hline & Total & 1394.739 & 947 & & & \\
\hline \multirow[t]{3}{*}{ (Ln) Revenues } & Between Groups & 588.327 & 1 & 588.327 & 290.786 & .000 \\
\hline & Within Groups & 2055.605 & 1016 & 2.023 & & \\
\hline & Total & 2643.933 & 1017 & & & \\
\hline \multirow[t]{3}{*}{ ROA } & Between Groups & .003 & 1 & .003 & .245 & .620 \\
\hline & Within Groups & 12.311 & 1061 & .012 & & \\
\hline & Total & 12.314 & 1062 & & & \\
\hline \multirow[t]{3}{*}{ ROE } & Between Groups & 9.570 & 1 & 9.570 & 5.326 & .021 \\
\hline & Within Groups & 1904.878 & 1060 & 1.797 & & \\
\hline & Total & 1914.449 & 1061 & & & \\
\hline \multirow[t]{3}{*}{ EPS } & Between Groups & 312744.613 & 1 & 312744.613 & .058 & .810 \\
\hline & Within Groups & 5690084094.341 & 1054 & 5398561.759 & & \\
\hline & Total & 5690396838.953 & 1055 & & & \\
\hline \multirow[t]{3}{*}{ Relative net cash flow } & Between Groups & .139 & 1 & .139 & 10.500 & .001 \\
\hline & Within Groups & 14.080 & 1061 & .013 & & \\
\hline & Total & 14.220 & 1062 & & & \\
\hline \multirow[t]{3}{*}{ Relative PPE } & Between Groups & 1.804 & 1 & 1.804 & 17.612 & .000 \\
\hline & Within Groups & 108.657 & 1061 & .102 & & \\
\hline & Total & 110.461 & 1062 & & & \\
\hline \multirow[t]{3}{*}{ Debt ratio } & Between Groups & 454.646 & 1 & 454.646 & 6.431 & .011 \\
\hline & Within Groups & 74936.976 & 1060 & 70.695 & & \\
\hline & Total & 75391.623 & 1061 & & & \\
\hline \multirow[t]{3}{*}{ Industry } & Between Groups & 27.710 & 1 & 27.710 & 1.776 & .183 \\
\hline & Within Groups & 16667.097 & 1068 & 15.606 & & \\
\hline & Total & 16694.807 & 1069 & & & \\
\hline
\end{tabular}


Table 10. Descriptive statistics

Factor: Lobbying

\begin{tabular}{|c|c|c|c|c|c|c|}
\hline & & $\mathrm{N}$ & Mean & St. deviation & Minimum & Maximum \\
\hline \multirow[t]{3}{*}{ (Ln) Equity } & & & & & & 10.439 \\
\hline & Lobbying firms & 281 & 8.332 & 1.283 & 3.689 & 13.582 \\
\hline & Total & 1049 & 7.322 & 1.344 & 1.761 & 13.582 \\
\hline \multirow[t]{3}{*}{ (Ln) Long-term debt } & Non-lobbying firms & 657 & 6.273 & 1.654 & -4.135 & 10.380 \\
\hline & Lobbying firms & 275 & 7.807 & 1.645 & 1.254 & 11.289 \\
\hline & Total & 932 & 6.726 & 1.793 & -4.135 & 11.289 \\
\hline \multirow[t]{3}{*}{ (Ln) Market value } & Non-lobbying firms & 677 & 7.522 & 0.978 & 2.234 & 10.574 \\
\hline & Lobbying firms & 271 & 8.838 & 1.238 & 5.244 & 11.201 \\
\hline & Total & 948 & 7.898 & 1.214 & 2.234 & 11.201 \\
\hline \multirow[t]{3}{*}{ (Ln) Revenues } & Non-lobbying firms & 737 & 6.714 & 1.470 & -1.008 & 10.779 \\
\hline & Lobbying firms & 281 & 8.415 & 1.288 & 4.702 & 10.745 \\
\hline & Total & 1018 & 7.183 & 1.612 & -1.008 & 10.779 \\
\hline \multirow[t]{3}{*}{ ROA } & Non-lobbying firms & 777 & 0.049 & 0.117 & -1.609 & 0.561 \\
\hline & Lobbying firms & 286 & 0.046 & 0.076 & -0.455 & 0.172 \\
\hline & Total & 1063 & 0.048 & 0.108 & -1.609 & 0.561 \\
\hline \multirow[t]{3}{*}{ ROE } & Non-lobbying firms & 776 & 0.089 & 0.766 & -20.157 & 2.007 \\
\hline & Lobbying firms & 286 & 0.303 & 2.256 & -1.011 & 35.325 \\
\hline & Total & 1062 & 0.147 & 1.343 & -20.157 & 35.325 \\
\hline \multirow[t]{3}{*}{ EPS } & Non-lobbying firms & 770 & 95.605 & 2606.389 & -6.929 & 9223.372 \\
\hline & Lobbying firms & 286 & 134.331 & 1278.795 & -7.339 & 9223.372 \\
\hline & Total & 1056 & 106.093 & 2322.443 & -7.339 & 9223.372 \\
\hline \multirow[t]{3}{*}{ Relative net cash flow } & Non-lobbying firms & 777 & 0.081 & 0.129 & 0.000 & 0.805 \\
\hline & Lobbying firms & 286 & 0.055 & 0.065 & 0.000 & 0.383 \\
\hline & Total & 1063 & 0.074 & 0.116 & 0.000 & 0.805 \\
\hline \multirow[t]{3}{*}{ Relative PPE } & Non-lobbying firms & 777 & 0.438 & 0.336 & 0.000 & 0.987 \\
\hline & Lobbying firms & 286 & 0.531 & 0.271 & 0.000 & 0.971 \\
\hline & Total & 1063 & 0.463 & 0.323 & 0.000 & 0.987 \\
\hline \multirow[t]{3}{*}{ Debt ratio } & Non-lobbying firms & 776 & 0.367 & 6.667 & -180.990 & 26.852 \\
\hline & Lobbying firms & 286 & 1.842 & 11.919 & -4.177 & 146.750 \\
\hline & Total & 1062 & 0.764 & 8.430 & -180.990 & 146.750 \\
\hline \multirow[t]{3}{*}{ Industry } & Non-lobbying firms & 781 & 5.840 & 4.124 & 2.000 & 19.000 \\
\hline & Lobbying firms & 289 & 5.480 & 3.436 & 2.000 & 18.000 \\
\hline & Total & 1070 & 5.740 & 3.952 & 2.000 & 19.000 \\
\hline
\end{tabular}

Table 11. ANOVA Results

Factor: Political Connections * Lobbying

\begin{tabular}{|c|c|c|c|c|c|c|}
\hline & & Sum of Squares & ddl & Mean Square & $\mathrm{F}$ & Sig. \\
\hline \multirow[t]{3}{*}{ (Ln) Total equity } & Between Groups & 356.354 & 1 & 356.354 & 242.981 & .000 \\
\hline & Within Groups & 1535.521 & 1047 & 1.467 & & \\
\hline & Total & 1891.875 & 1048 & & & \\
\hline \multirow[t]{3}{*}{ (Ln) Long-term debt } & Between Groups & 418.247 & 1 & 418.247 & 151.142 & .000 \\
\hline & Within Groups & 2573.538 & 930 & 2.767 & & \\
\hline & Total & 2991.784 & 931 & & & \\
\hline \multirow[t]{3}{*}{ (Ln) Market value } & Between Groups & 352.565 & 1 & 352.565 & 320.029 & .000 \\
\hline & Within Groups & 1042.174 & 946 & 1.102 & & \\
\hline & Total & 1394.739 & 947 & & & \\
\hline \multirow[t]{3}{*}{ (Ln) Revenues } & Between Groups & 567.848 & 1 & 567.848 & 277.895 & .000 \\
\hline & Within Groups & 2076.085 & 1016 & 2.043 & & \\
\hline & Total & 2643.933 & 1017 & & & \\
\hline \multirow[t]{3}{*}{ ROA } & Between Groups & .009 & 1 & .009 & .767 & .381 \\
\hline & Within Groups & 12.305 & 1061 & .012 & & \\
\hline & Total & 12.314 & 1062 & & & \\
\hline \multirow[t]{3}{*}{ ROE } & Between Groups & 15.229 & 1 & 15.229 & 8.500 & .004 \\
\hline & Within Groups & 1899.220 & 1060 & 1.792 & & \\
\hline & Total & 1914.449 & 1061 & & & \\
\hline \multirow[t]{3}{*}{ EPS } & Between Groups & 2792737.144 & 1 & 2792737.144 & .518 & .472 \\
\hline & Within Groups & 5687604101.809 & 1054 & 5396208.825 & & \\
\hline & Total & 5690396838.953 & 1055 & & & \\
\hline \multirow[t]{3}{*}{ Relative net cash flow } & Between Groups & .144 & 1 & .144 & 10.826 & .001 \\
\hline & Within Groups & 14.076 & 1061 & .013 & & \\
\hline & Total & 14.220 & 1062 & & & \\
\hline
\end{tabular}




\begin{tabular}{llccccc} 
Relative PPE & Between Groups & 1.223 & 1 & 1.223 & 11.877 & .001 \\
& Within Groups & 109.238 & 1061 & .103 & & \\
Debt ratio & Total & 110.461 & 1062 & & 7.967 & .005 \\
& Between Groups & 562.423 & 1 & 562.423 & \\
Industry & Within Groups & 74829.200 & 1060 & 70.594 & & \\
& Total & 75391.623 & 1061 & & .046 & .830 \\
& Between Groups & .717 & 1 & .717 & \\
\hline
\end{tabular}

Table 12. Descriptive statistics

Factor: Political Connections * Lobbying

\begin{tabular}{|c|c|c|c|c|c|c|}
\hline & & $\mathrm{N}$ & Mean & Std Dev. & Minimum & Maximum \\
\hline \multirow[t]{3}{*}{ (Ln) Equity } & & & & & & 10.439 \\
\hline & Lobbying and PC firms & 207 & 8.498 & 1.302 & 3.689 & 13.582 \\
\hline & Total & 1049 & 7.322 & 1.344 & 1.761 & 13.582 \\
\hline \multirow[t]{3}{*}{ (Ln) Long-term debt } & Non-lobbying and Non-PC firms & 725 & 6.368 & 1.663 & -4.135 & 10.380 \\
\hline & Lobbying and PC firms & 207 & 7.980 & 1.666 & 1.254 & 11.289 \\
\hline & Total & 932 & 6.726 & 1.793 & -4.135 & 11.289 \\
\hline \multirow[t]{3}{*}{ (Ln) Market value } & Non-lobbying and Non-PC firms & 745 & 7.580 & 1.005 & 2.234 & 10.776 \\
\hline & Lobbying and PC firms & 203 & 9.066 & 1.200 & 6.175 & 11.201 \\
\hline & Total & 948 & 7.898 & 1.214 & 2.234 & 11.201 \\
\hline \multirow[t]{3}{*}{ (Ln) Revenues } & Non-lobbying and Non-PC firms & 806 & 6.800 & 1.469 & -1.008 & 10.779 \\
\hline & Lobbying and PC firms & 212 & 8.640 & 1.267 & 5.098 & 10.745 \\
\hline & Total & 1018 & 7.183 & 1.612 & -1.008 & 10.779 \\
\hline \multirow[t]{3}{*}{ ROA } & Non-lobbying and Non-PC firms & 851 & 0.047 & 0.117 & -1.609 & 0.561 \\
\hline & Lobbying and PC firms & 212 & 0.054 & 0.052 & -0.169 & 0.165 \\
\hline & Total & 1063 & 0.048 & 0.108 & -1.609 & 0.561 \\
\hline \multirow[t]{3}{*}{ ROE } & Non-lobbying and Non-PC firms & 850 & 0.087 & 0.736 & -20.157 & 2.007 \\
\hline & Lobbying and PC firms & 212 & 0.387 & 2.612 & -0.863 & 35.325 \\
\hline & Total & 1062 & 0.147 & 1.343 & -20.157 & 35.325 \\
\hline \multirow[t]{3}{*}{ EPS } & Non-lobbying and Non-PC firms & 844 & 131.867 & 2597.471 & -7.339 & 9223.372 \\
\hline & Lobbying and PC firms & 212 & 3.484 & 3.918 & -5.665 & 19.893 \\
\hline & Total & 1056 & 106.093 & 2322.443 & -7.339 & 9223.372 \\
\hline \multirow[t]{3}{*}{ Relative net cash flow } & Non-lobbying and Non-PC firms & 851 & 0.079 & 0.125 & 0.000 & 0.805 \\
\hline & Lobbying and PC firms & 212 & 0.050 & 0.059 & 0.000 & 0.383 \\
\hline & Total & 1063 & 0.074 & 0.116 & 0.000 & 0.805 \\
\hline \multirow[t]{3}{*}{ Relative PPE } & Non-lobbying and Non-PC firms & 851 & 0.447 & 0.333 & 0.000 & 0.987 \\
\hline & Lobbying and PC firms & 212 & 0.531 & 0.267 & 0.000 & 0.952 \\
\hline & Total & 1063 & 0.463 & 0.323 & 0.000 & 0.987 \\
\hline \multirow[t]{3}{*}{ Debt ratio } & Non-lobbying and Non-PC firms & 850 & 0.401 & 6.381 & -180.990 & 26.852 \\
\hline & Lobbying and PC firms & 212 & 2.221 & 13.814 & -4.177 & 146.750 \\
\hline & Total & 1062 & 0.764 & 8.430 & -180.990 & 146.750 \\
\hline \multirow[t]{3}{*}{ Industry } & Non-lobbying and Non-PC firms & 857 & 5.750 & 4.141 & 2.000 & 19.000 \\
\hline & Lobbying and PC firms & 213 & 5.690 & 3.085 & 2.000 & 12.000 \\
\hline & Total & 1070 & 5.740 & 3.952 & 2.000 & 19.000 \\
\hline
\end{tabular}

In conclusion, possession of political capital appears to make it possible for firms to differentiate themselves in a positive way, in view of the statistics showing that firms with political capital exhibit, on average, higher equity (8.49 vs. 7.03 ), higher long-term debt (7.97 vs. 6.36), higher market value (9.06 vs. 7.57 ) and higher revenues (8.63 vs. 6.80). These results provide an initial confirmation of our third hypothesis and are in line with previous studies demonstrating that politically connected firms obtain greater financial resources, such as loans or government contracts (Dicko, 2016; Goldman et al., 2013).

\subsection{Results of Correlation Analyses}

Correlation analyses provide insights into the bivariate relationships. Table 13 reports that having political connections is positively and significantly correlated to equity, long-term debt, market value, and revenues. The same type of observation is noted for lobbying, and a significant relationship is obtained for ROE. When the firm uses both types of political capital (political connections + lobbying), there is a positive and significant correlation with the main variables that measure the firm's financing sources and financial performance, i.e. equity, long-term debt, market value, revenues and ROE. Thus, it can be initially concluded that political capital 
enables a firm not only to access capital (equity and debt), but also to improve financial performance. Will this conclusion be corroborated by multivariate analyses?

Table 13. Results of Pearson Correlation Analyses

\begin{tabular}{|c|c|c|c|c|c|c|c|c|c|c|c|}
\hline & 1 & 2 & 3 & 4 & 5 & 6 & 7 & 8 & 9 & 10 & 11 \\
\hline 1 Political connections & 1 & & & & & & & & & & \\
\hline 2 Lobbying & $.409^{* *}$ & 1 & & & & & & & & & \\
\hline 3 Political connections and Lobbying & $.602^{* *}$ & $.820^{* *}$ & 1 & & & & & & & & \\
\hline 4 (Ln) Total equity & $.318^{* *}$ & $.455^{* *}$ & $.434^{* *}$ & 1 & & & & & & & \\
\hline 5 (Ln) Long-term debt & $.275^{* *}$ & $.391^{* *}$ & $.374^{* * *}$ & $.710^{* *}$ & 1 & & & & & & \\
\hline 6 (Ln) Market value & $.347^{* *}$ & $.490^{* *}$ & $.503^{* *}$ & $.845^{* *}$ & $.695^{* *}$ & 1 & & & & & \\
\hline 7 (Ln) Revenues & $.403^{* *}$ & $.472^{* *}$ & $.463^{* *}$ & $.638^{* *}$ & $.600^{* * *}$ & $.704^{* *}$ & 1 & & & & \\
\hline 8 ROA & .060 & -.015 & .027 & -.042 & $.095^{* *}$ & $.139^{* *}$ & $.117^{* *}$ & 1 & & & \\
\hline 9 ROE & .048 & $.071^{*}$ & $.089^{* *}$ & $-.127^{* *}$ & $.072^{*}$ & .051 & $.088^{* *}$ & $.149^{* * *}$ & 1 & & \\
\hline 10 EPS & .023 & .007 & -.022 & .021 & .007 & $.405^{* *}$ & -.018 & -.003 & -.002 & 1 & \\
\hline 11 Relative net cash flow & $-.159^{* *}$ & $-.099^{* *}$ & $-.101^{* * *}$ & $-.353^{* * *}$ & $-.393^{* *}$ & $-.261^{* *}$ & $-.344^{* * *}$ & .000 & -.016 & -.026 & 1 \\
\hline
\end{tabular}

\subsection{Results of Regression Analyses}

We analyze the impact of political capital (plus other variables) on the main indicators of financial performance that were selected for this study, i.e. ROA, ROE and EPS. To this end, we use a general linear regression model. All three models are statistically highly significant $\left(\mathrm{p}\right.$ value $=0.000$ ). The model with ROA has an adjusted $\mathrm{R}^{2}$ of 0.182 , while the one with ROE has an adjusted $\mathrm{R}^{2}$ of 0.874 (and is the model with the greatest explanatory power). Lastly, the model with EPS has an adjusted $R^{2}$ of 0.485 (See Table 14 for details).

Table 14. Results of General Linear Regressions

Dependent Variables: ROA, ROE and EPS

\begin{tabular}{|c|c|c|c|c|c|c|}
\hline Source & Dependent Variable & $\begin{array}{c}\text { Type III Sum of } \\
\text { Squares }\end{array}$ & ddl & Mean Square & $\mathrm{F}$ & Significance \\
\hline \multirow[t]{3}{*}{ Corrected model } & ROA & $.192^{\mathrm{a}}$ & 16 & .012 & 3.338 & .000 \\
\hline & ROE & $1275.169^{\mathrm{b}}$ & 16 & 79.698 & 73.771 & .000 \\
\hline & EPS & $1012.902^{c}$ & 16 & 63.306 & 10.870 & .000 \\
\hline \multirow[t]{3}{*}{ Constant } & ROA & .034 & 1 & .034 & 9.548 & .002 \\
\hline & ROE & .370 & 1 & .370 & .343 & .559 \\
\hline & EPS & 27.544 & 1 & 27.544 & 4.729 & .031 \\
\hline \multirow[t]{3}{*}{ Political connections } & ROA & .000 & 1 & .000 & .030 & .863 \\
\hline & ROE & .063 & 1 & .063 & .058 & .810 \\
\hline & EPS & 20.843 & 1 & 20.843 & 3.579 & .060 \\
\hline \multirow[t]{3}{*}{ Lobbying } & ROA & .000 & 1 & .000 & .064 & .800 \\
\hline & ROE & .408 & 1 & .408 & .378 & .540 \\
\hline & EPS & 30.541 & 1 & 30.541 & 5.244 & .023 \\
\hline \multirow[t]{3}{*}{ PC*Lobbying } & ROA & .003 & 1 & .003 & .840 & .361 \\
\hline & ROE & .562 & 1 & .562 & .520 & .472 \\
\hline & EPS & 58.153 & 1 & 58.153 & 9.985 & .002 \\
\hline \multirow[t]{3}{*}{ Industry } & ROA & .119 & 9 & .013 & 3.677 & .000 \\
\hline & ROE & 27.903 & 9 & 3.100 & 2.870 & .004 \\
\hline & EPS & 674.070 & 9 & 74.897 & 12.860 & .000 \\
\hline \multirow[t]{3}{*}{ Firm size } & ROA & .017 & 1 & .017 & 4.743 & .031 \\
\hline & ROE & .362 & 1 & .362 & .335 & .564 \\
\hline & EPS & 17.451 & 1 & 17.451 & 2.996 & .085 \\
\hline \multirow[t]{3}{*}{ Debt ratio } & ROA & .001 & 1 & .001 & .141 & .707 \\
\hline & ROE & 1020.362 & 1 & 1020.362 & 944.484 & .000 \\
\hline & EPS & .547 & 1 & .547 & .094 & .760 \\
\hline \multirow[t]{3}{*}{ Relative net cash flow } & ROA & .016 & 1 & .016 & 4.505 & .035 \\
\hline & ROE & .481 & 1 & .481 & .446 & .505 \\
\hline & EPS & 60.912 & 1 & 60.912 & 10.459 & .001 \\
\hline \multirow[t]{3}{*}{ Relative PPE } & ROA & .002 & 1 & .002 & .473 & .493 \\
\hline & ROE & .228 & 1 & .228 & .211 & .646 \\
\hline & EPS & 229.670 & 1 & 229.670 & 39.436 & .000 \\
\hline
\end{tabular}




\begin{tabular}{llccc} 
Error & ROA & .547 & 152 & .004 \\
& ROE & 164.211 & 152 & 1.080 \\
Total & EPS & 885.229 & 152 & 5.824 \\
& ROA & 1.057 & 169 & \\
Corrected total & ROE & 1464.977 & 169 & \\
& EPS & 2821.505 & 169 & \\
& ROA & .740 & 168 & \\
& ROE & 1439.381 & 168 & \\
a. $\mathrm{R}^{2}=.260$ (adjusted $\left.\mathrm{R}^{2}=.182\right)$ & 1898.130 & 168 & \\
b. $\mathrm{R}^{2}=.886$ (adjusted $\left.\mathrm{R}^{2}=.874\right)$ & & & \\
c. $\mathrm{R}^{2}=.534$ (adjusted $\left.\mathrm{R}^{2}=.485\right)$ & & & \\
\hline
\end{tabular}

We find that ROA and ROE are not significantly influenced by either the political connections or lobbying variable, or even a combination of both variables.

Only EPS is influenced significantly by political connections and lobbying, and very significantly by a combination of both variables (i.e. political capital). Thus, the fact of carrying out concurrent political activities provides more positive effects than conducting one political activity at a time. Building political capital therefore has a synergistic effect. These results confirm our research hypotheses, at least for one of the financial performance indicators.

\section{Conclusion}

The main purpose of this study was to examine the combined impact of two corporate political activities (as political capital) on key firm financial and accounting indicators. For this purpose, we used data on Canadian companies listed on the S\&P/TSX composite index covering a five-year period (2012 through 2016).

Two industries dominate in terms of volume of political activities, representing more than $50 \%$ of our sample: mining (quarries, and oil and gas extraction) and manufacturing. As they grapple with escalating social and environmental issues around the world, these two industries must reinvent themselves and be more proactive in fighting regulation. Some companies are responding, as shown by the surge in anti-climate change lobbying in the U.S. (Brulle, 2018).

Firms with political connections that engage in lobbying activities (considered a form of political capital) generally fare better than firms lacking this capital, enjoying, on average, higher equity, long-term debt and market value. As a result, they obtain more financing than the other group.

According to bivariate statistical analyses (ANOVA and correlation), firms with political connections and lobbying activities (either individually or both) exhibit better financial indicators, confirming our research hypotheses. In fact, certain previous studies show that politically connected firms are usually those with greater financial means.

According to regression analysis results, political connections and lobbying have a positive and very significant effect on EPS. In fact, when the two activities are taken together, their impact on EPS is greater than when each activity is considered separately.

The current study is the first Canadian investigation to examine the combined effect of corporate political activities on the firm's key financial and accounting indicators. Results show that conducting at least two political activities at once produces more positive synergistic effects than separate activities do. These results confirm the fact that capital attracts capital (from Bourdieu' social capital theory). Having political capital allows firms to obtain financial capital. Thus, to acquire more capital and subsequently more resources, firms must continue accumulating political capital through political activities.

Our results also show that corporate political activities are more prevalent in industries subject to greater uncertainty, i.e. mining, oil and gas, manufacturing, and information and culture. In fact, these industries require sizeable financial investments and are more likely to face heavier consequences from environmental uncertainties. Moreover, in view of the greater challenges associated with the serious environmental issues confronting them, the oil and manufacturing industries are particularly targeted by national and international regulations intended to reduce $\mathrm{CO} 2$ emissions. According to resource dependence theory, organizations facing complex environmental challenges need to find ways to overcome these barriers and access key resources from their environment (Pfeffer and Salancik, 1978). In the Canadian context, these industries seem to be responding by using a combination of political activities to acquire financial resources. Our results therefore confirm the 
resource dependence theory assumption whereby political activities help firms face environmental uncertainties and obtain access to the key resources they need.

The findings set out in this study align with several prior investigations. They generally show that politically connected companies have easier access to key financial resources. Wang (2014) examined a sample of 112 listed companies out of the top 500 recipients of the U.S. Department of Defense contracts in 2008 and found that the contracts generated $22.35 \%$ of the total revenue of politically connected companies but only $8.68 \%$ of the revenue of non-connected companies. In the Canadian context, Dicko (2016) shows a correlation between obtaining government contracts and the political connections of listed companies. The current study thus supports prior claims that corporate political capital (in the form of corporate political activities) is one of the main strategic levers that can help firms obtain a decided competitive advantage (Getz, 1997; Hadani, 2007).

\section{References}

Ang, J. S., Ding, D. K., \& Thong, T. Y. (2013). Political Connections and Firm Value. Asian Development Review, 30(2), 131-166. https://doi.org/10.1162/ADEV_a_00018

Ballet, J. (2005). Stakeholders et capital social. Revue Française de Gestion, 31(156), 77-91. https://doi.org/10.3166/rfg.156.77-91

Boubakri, N., Mansi, S. A., \& Saffar, W. (2013). Political Institutions, Connectedness, and Corporate Risk-Taking. Journal of International Business Studies, 44, 195-215. https://doi.org/10.1057/jibs.2013.2

Bourdieu, P. (1979). La distinction : critique sociale du jugement. Paris: Les Éditions de Minuit.

Bourdieu, P. (1980). Le capital social: notes provisoires. Actes de la Recherche en Sciences Sociales, 31, 2-3. https://doi.org/10.3406/arss.1980.2077

Bourdieu, P. (1982). Les rites d'institution. Actes de la Recherche en Sciences Sociales, 43, 58-63. https://doi.org/10.3406/arss.1982.2159

Bourdieu, P. (1986). The Forms of Capital. In J. G. Richardson (Ed.), Handbook of Theory and Research for the Sociology of Education (pp. 241-258). Westport, CT: Greenwood.

Bourdieu, P. (2000). Les structures sociales de l'économie. Paris: Éditions du Seuil.

Breton, G., \& Pesqueux, Y. (2006). Business in society or an integrated vision of governance. Society and Business Review, 1(1), 7-27. https://doi.org/10.1108/17465680610643319

Brockman, P., Rui, O. M., \& Zou, H. (2013). Institutions and the performance of politically connected M\&As. Journal of International Business Studies, 44, 833-852. https://doi.org/10.1057/jibs.2013.37

Brulle, R. J. (2018). The climate lobby: A sectoral analysis of lobbying spending on climate change in the USA, 2000 to 2016. Climatic Change, 149(3-4), 289-303. https://doi.org/10.1007/s10584-018-2241-z

Chen, H., Parsley, D., \& Yang, Y. W. (2015). Corporate lobbying and firm performance. Journal of Business Finance and Accounting, 42(3), 444-481. https://doi.org/10.1111/jbfa.12109

Choi, J. S., Kwak, Y. M., \& Choe, C. (2010). Corporate social responsibility and corporate financial performance: Evidence from Korea. Aust. J. Manag., 35(3), 291-311. https://doi.org/10.1177/0312896210384681

Claessens, S., Feijen, E., \& Laeven, L. (2008). Political Connections and Preferential Access to Finance: The Role of Campaign Contributions. Journal of Financial Economics, 88, 554-580. https://doi.org/10.1016/j.jfineco.2006.11.003

Dicko, S. (2016). Firms political connections and winning government contracts. International Journal of Economics and Finance, 8(2), 19-32. https://doi.org/10.5539/ijef.v8n2p19

Dicko, S. (2020). Does ownership structure influence the relationship between firms' political connections and financial performance? Int. J. Corporate Governance, 11(1), 47-75. https://doi.org/10.1504/IJCG.2020.107405

Dicko, S., \& El Ibrami, H. (2013). Directors' Connections, Financial Resources and Performance: An In-Depth Analysis of Canadian Companies. International Journal of Business and Management, 8(10), 1-14. https://doi.org/10.5539/ijbm.v8n10p1

Dicko, S., \& Khemakhem, H. (2015). S\&P/TSX 300 Companies' Political Connections, Compliance with Board of Directors Regulations and Financial Performance. International Journal of Business and Management, 10(1), 14-24. https://doi.org/10.5539/ijbm.v10n1p14 
Faccio, M. (2006). Politically Connected Firms. The American Economic Review, 96(1), 369-386. https://doi.org/10.1257/000282806776157704

Fuchs, D., \& Lederer, M. L. (2007). The Power of Business. Business and Politics, 9(3), 1-17. https://doi.org/10.2202/1469-3569.1214

Getz, K. A. (1997). Research in corporate political action: Integration and assessment. Business and Society, 36(1), 32-72. https://doi.org/10.1177/000765039703600103

Goldman, E., Rocholl, J., \& So, J. (2009). Do Politically Connected Boards Affect Firm Value? The Review of Financial Studies, 22(6), 2331-2360. https://doi.org/10.1093/rfs/hhn088

Goldman, E., Rocholl, J., \& So, J. (2013). Politically Connected Boards of Directors and the Allocation of Procurement Contracts. Review of Finance, 17, 1617-1648. https://doi.org/10.1093/rof/rfs039

Hadani, M. (2007). Family Matters: Founding Family Firms and Corporate Political Activity. Business \& Society, 46(4), 395-428. https://doi.org/10.1177/0007650306293394

Kowal, M. S. (2018). Corporate politicking, together: Trade association ties, lobbying, and campaign giving. Business and Politics, 20(1), 98-131. https://doi.org/10.1017/bap.2017.14

Li, A., \& Xia, X. (2013). Political Connections, Financial Crisis and Firm's Value: Evidence from Chinese Listed Firms. International Journal of Business and Management, 8(18), 63-77. https://doi.org/10.5539/ijbm.v8n18p63

Pfeffer, J. (1972). Size and Composition of Corporate Boards-of-directors - the Organization and its Environment. Administrative Science Quarterly, 17(2), 218-228. https://doi.org/10.2307/2393956

Pfeffer, J. (1973). Size, Composition, and Function of Hospital Boards-of-directors - a Study of Organization-environment Linkage. Administrative Science Quarterly, 18(3), 349-364. https://doi.org/10.2307/2391668

Pfeffer, J. (1981). Power in Organizations. Marshfield, Mass: Pitman.

Pfeffer, J., \& Salancik, G. R. (1978). The External Control of Organizations: A Resource Dependence Perspective. New York: Harper \& Row.

Portes, A. (1998). Social Capital: Its Origins and Applications in Modern Sociology. Annual Review of Sociology, 24, 1-24. https://doi.org/10.1146/annurev.soc.24.1.1

Skaife, H. A., Veenman, D., \& Werner, T. (2017). Corporate Lobbying and CEO Pay. Presented October 4, 2017.

Unsal, O., Hassan, M. K., \& Zirek, D. (2016). Corporate Lobbying, CEO Political Ideology and Firm Performance. Journal of Corporate Finance, 38, 126-149. https://doi.org/10.1016/j.jcorpfin.2016.04.001

Wang, C. (2014). Political Connections of the Boards of Directors and Department of Defense Contractors' Excessive Profits. Journal of Public Procurement, 14(1), 96-122.

https://doi.org/10.1108/JOPP-14-01-2014-B004

\section{Copyrights}

Copyright for this article is retained by the author(s), with first publication rights granted to the journal.

This is an open-access article distributed under the terms and conditions of the Creative Commons Attribution license (http://creativecommons.org/licenses/by/4.0/). 